\title{
Assessing the Impacts of Political and Economic Openness on GDP Growth: Case of Asian Countries
}

\author{
Ichsan Zulkarnaen' \\ Ministry of National Development Planning/BAPPENAS
}

\begin{abstract}
The economic performance of a nation is measured in the gross domestic product (GDP). Over the last two decades, the rising of economic development in East Asian accompanies openness in economic and political environment more than ever before. This paper seeks to figure out the pattern of how economic openness and political openness of Asian countries influence GDP growth by using panel method. We treat the GDP growth as the dependent variable and political rights, civil rights, trade liberalization, foreign direct investment as independent variables. I draw time-series data for 11 Asian countries: China, Japan, South Korea, Indonesia, Malaysia, Philippines, Thailand, Singapore, India, Pakistan and Bangladesh from 1984 to 2011 using Freedom house, World Bank and United Nations Commission for Trade and Development (UNCTAD). Results, even though imperfect, show that high levels of political openness and economic openness indeed improve the economic development of China and Indonesia.
\end{abstract}

Keywords: GDP growth, Political Openness, Economic Openness, Asian Countries, Panel data 


\section{Assessing the Impacts of Political and Economic Openness on GDP Growth: Case of Asian Countries}

Ichsan Zulkarnaen, BAPPENAS

\section{Introduction}

\subsection{Background}

In the last two decades, the development of the world economy has undergone significant changes, reflected by shifting the focus of the economy from Europe and America to the Asian Pacific region, in particular East Asian Countries such as Japan, Korea and China (Haryadi, 2008). In addition, changes in the world economic order are also marked by the opening of the world economy. Economies are increasingly integrated across countries, thus economic turmoil in one country or a particular region will result in economic turmoil not only in that country or region itself, but also in other countries in accordance with the first' country's level of economic openness.

Nowadays countries prefer to participate in an open economy, allowing export and import, both on the flow of goods and services and also investment in capital and human resources. This is in line with a study by Dollar and Kraay (2000), which provided evidence that the countries with more open economies are experiencing more rapid economic growth compared to countries with relatively closed economies in the period 1970-1990.

Along with economic openness, during the last two decades political and civil liberties have spread out around the world (Griswold, 2007). Many countries "have successfully transformed themselves into functioning democracies that protect basic civil and political freedoms" (Griswold, 2007).

However, the openness in politics and economies has led to at least two different views; pro liberalization and anti-liberalization. The adherents of liberalization argue that economic openness will have a positive impact on the economy of a country that is characterized by a decline in the price of imported products, the increasing purchasing power of consumers, and the increased competitiveness of domestic products in the export market, which in turn increases the overall GDP of the country. This is in line with studies conducted by Bhagwati (1993), using the Hecksher-Ohlin theory, that free trade would benefit both parties. Although antiliberalization followers acknowledge that economic openness can provide benefits, conditions of economic power in their respective countries are quite varied, which of course will bring benefits, even differences. There is a trend of negative impacts for countries whose economies are still developing and underdeveloped. This is supported by a number of studies such as Michaely (1977), Heller and Porter (1978), and Balassa (1978) which proved that the positive impact of economic openness on the economy of each country impact is not the same.

Numerous studies have also demonstrated a positive correlation between economic growth and political rights such as Helliwell (1994), Feng (1997) and, Heo and Tan (2001). However, other researches such as Przeworski and Limongi (1993, 1997) and Barro (1996) found little to no correlation between political rights, democracy and economic growth

This short paper aims at analyzing the impacts of the political and economic elements on the economic performance in Asian. I assume that this regional economic performance is characterized by mixed conditions of economic and political openness. This study will proceed as follows. In the first section, I introduce 
a literature review regarding the impact of political and economic openness on economic performance. In the second section, I propose a specific model based on theoretical models and a literature review of the models. Sign hypotheses are shown in the third section, followed by section focusing on the discussion of the results of this study and also the conclusion. Finally, I will propose several policy implications.

\section{Literature Review}

The impact between political and economic openness on economic performance remains controversial. There have been several studies done already on the association of political openness economic openness and their impact on economic performance. In this part, we will introduce some of the important research that has been done concerning this topic.

\subsection{Pro Political Openness}

Feng (1997, p.398) asserts "that democracy is likely to have a significant indirect effect on economic growth through its impact on political stability".

Berggren (2003, p.205) states "Free markets are conducive to economic growth, which is why measures such as privatization, freedom to establish new businesses, freer pricing, more flexible contract laws, and less regulation of domestic and international trade and of capital transactions are important". He also states "An impartial and strong judicial system that protects private-property rights and upholds contracts and agreements is central for a strong economic development"(Berggren, 2003, p.205).

Vega-Gordillo and Alvarez-Arce (2003), have quantified a direct correlation between the levels of civil, economic, and political freedom and the rate of national economic growth. Vega-Gordillo and Alvarez-Acre (2003, also cited in Nalley and Barkley, 2005. p.124) proclaimed "that democracy should facilitate economic growth through the development of an institutional framework that is more compatible with incentives to engage in productive transactions".

Wittman (1989, 1995) and Baba (1997, also cited in Nalley and Barkley, 2005. p.125) argued that "democracy enables the development of institutions that guarantee the transparency of the policy-making process and that institutions such as property rights are crucial to economic growth."

Rodrick (2000) demonstrated empirically that participatory democracies are associated with higher-quality growth, defined as more predictable long-term growth rates, greater short-term stability, better resilience to adverse shocks, and a broader distribution of wealth.

\subsection{Anti Political Openness}

However, Przeworski and Limongi $(1993,1997)$ and Barro (1996 also cited in Nalley and Barkley, 2005. p.126) found "little to no correlation between political rights, democracy and economic growth." Barro (1996. also cited in Nalley and Barkley 2005. p. 126) "found a nonlinear relationship between democracy and growth: democracy enhanced growth at low levels of political rights or freedom, but depressed growth as more political freedom was obtained." "Although there are exceptions throughout the literature, economic theory suggests that the adoption of economic freedom by a society is more likely to promote higher economic growth than a society that is characterized by lower levels of economic freedom."(p. 126)

\subsection{Pro Economic Openness}

Study which has been done in several new industrial countries (NICs) such as Hong Kong, Korea and Singapore showed that trade liberalization creates fairly 
rapid growth for each country (Aggarwal and Agmon, 1990).

Similar opinion was also expressed by Mulyono (1997) showing that world trade is believed to play a major role in enhancing global prosperity. Therefore, measures aimed to reduce and eliminate trade barriers need to be supported.

Matusz et al. (1999) who conducted a survey of 50 empirical studies found that the implementation of trade liberalization will increase employment in the field of agricultural and industrial products and eventually it will reduce poverty.

Many studies also have been carried out to investigate the fundamental theories of Foreign Direct Investment (FDI), the advantages of FDI, and the relationship between FDI and economic development. Examples are Driffield and Love (2007), and Tian (2007). All of them suggest that foreign direct investment has a positive effect on economic performance.

\subsection{Anti Economic Openness}

Although in one side economic openness can provide benefits, however, conditions of economic power in their respective countries are quite varied which of course will bring benefits even differences there is a trend with negative impacts for countries whose economies are still developing and underdeveloped. This is supported by a number of studies such as Daly (1993), Nayyar (1997), and Feridhanusetyawan and Rizal (1998), which proves that the positive impact of economic openness on the economy caused each countries are not the same.

Daly (1993) shows that free trade will increase the production the world but without assurance that all the countries which involved will be benefited. Also, study conducted by Nayyar (1997) states that the benefits of trade liberalization accumulate only in a small part of developing countries that the countries that fall into the category of more advanced such as Thailand, Korea and China.

Feridhanusetyawan and Rizal (1998) show that with trade liberalization, higher economic welfare will be achieved. However, the welfare cannot be enjoyed equally by all countries. Even countries in the regions such as Latin America, parts of Europe, the Middle East, and former Soviet Union countries are negatively impacted.

While there have been plenty of studies done on political and economic openness, there have been limited studies done on a single country and on a time series basis. In this study, we investigate the relationship between political and economic openness and economic performance focusing only on China and Indonesia. Also, in this study we try to incorporate economic crisis as an indicator which is none of the study mentioned above have tried to do.

\section{Theoretical Model}

Political openness is defined as citizen's rights to participate in politics (Bessette, 2012). Many researchers have tried to assess political openness, such as Garribay and colleagues who identify six channels: 1) electoral participation, 2) competition, 3) accountability, 4) rule of law, 5) transparency and 6) interfaces (Garribay, et al. 2008). Along this line, Freedom House also measures political rights as one indicator of political openness by using the Gastil concept of political rights. The Gastil's concept of political rights is indicated by this basic definition: "Political rights are rights to participate meaningfully in the political process" (Barro, 1999, page 160). "In a democracy this means the right of all adults to vote and compete for public office, and for elected representatives to have a decisive vote on public policies"(Barro, 1999, p. 160-161). "Elections are held freely, fairly and competitively in democratic countries and opposition parties play an important role in checks and balances"(Feng, 2003, p. 44). 
Also, the protection of human rights through the provision of civil liberties is one of the most fundamental indicators in political openness (Benyishay, 2010). "Property rights are usually determined at the most elementary level as the right to consume services of, the right to generate income from and the right to alienate an asset"(Benyishay, 2010, p. 284).

Economic openness is generally considered trade liberalization where its effect is reflected in the performance of exports and imports (Dominte, 2005). The exports illustrate the penetration of internal products on foreign markets and the imports reflect the opportunities to accumulate upper quality resources that sustain the economy.

Theoretically, there seems to be little doubt that long-run economic growth should be positively influenced by economic openness. Most theoretical models generate this relationship through transfers in technology and innovation which are facilitated by openness and trade. The more open the economy is, the easier it becomes to import and adopt technological innovations from higher-productivity trading partners, and thus the higher the growth rate (Karras, 2003).

Fatah et al. (2012) developed a model to investigate the impact of political freedom, economic openness and human development on real GDP per-capita in China, Indonesia and Malaysia. In the model, they included birth rate and life expectancy as a demographic variable. The results showed that openness has a positive, strong association with GDP per-capita. The estimated coefficients have the expected signs and are statistically significant. Also, it showed that higher fertility rate has a strong, negative and large effect on economic growth for all three countries. However, the result also indicated that life expectancy at birth is not statistically significant in Indonesia even at the 10\% level.

Based on several studies and theoretical background explained above, I try to introduce a model which is going to be implemented in this study. The dependent variable and independent variables in this study are based on similar time series cross sectional data constructed by Fatah et al. (2012) except we eliminate the demographic variable since I think that the result is quite ambiguous. In this regard, our approach also quite differs from the approach taken by other researchers in the sense that I also incorporate GDP per capita in this study as a control variable.

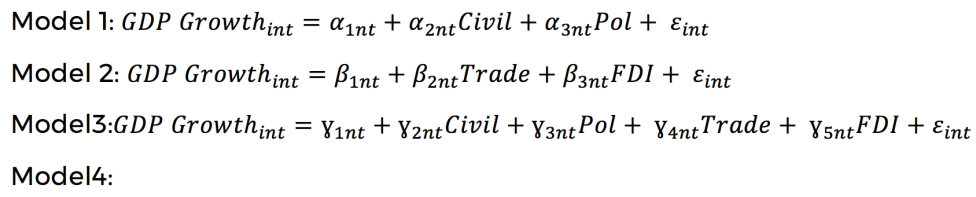

Relations of the above-mentioned variables will be analyzed using software Stata12. Multivariate analysis using Pooled Ordinary Least Squares (OLS) will be run to understand the relationship between independent and dependent variables in Asian countries.

Given the type of data in this study, we expect that there will be autocorrelation and heteroskedasticity problems because this study deals with time series and cross sectional data. Also, it is quite possible that since we are dealing with time series 
data, we expect that the issue of multicollinearity would occur particularly between civil liberties and political rights.

When autocorrelation and heteroskedasticity issues are present in the data set, the OLS is still unbiased but not efficient.

In the case when hetersokedasticity and autocorrelation occurs, I, then, apply the Robust Standard Error to correct not only heteroskedasticity but also autocorrelation.

\section{Hypothesis}

According to some studies that are described above, there is a significant relationship between the levels of economic and political openness and economic performance. In this study, we establish hypotheses as follows:

1) In terms of Civil Liberties $\mathrm{HO}=\mathrm{O}$ : There is no relationship between Civil Liberties and GDP Growth.

Halt $<0$ : There is a negative relationship between Civil Liberties and GDP growth. It means that if the index in civil liberties decreases, then we expect the GDP growth to increase.

2) In terms of Political Rights

$\mathrm{HO}=\mathrm{O}:$ There is no relationship between Political Rights and GDP growth.

Halt < O: There is a negative relationship between Political Rights and GDP growth. It means that if the index in political rights decreases, then we expect the GDP growth to increase

3) In terms of Trade Liberalization

$\mathrm{HO}=\mathrm{O}:$ There is no relationship between trade liberalization and GDP growth.

Halt: > O: There is a positive relationship between trade liberalization and GDP growth.

4) In terms of FDI

$\mathrm{HO}=\mathrm{O}$ : There is no relationship between FDI and GDP growth.

Halt: > O: There is a positive relationship between FDI and GDP growth.

Table 1. Hypothesis Table

\begin{tabular}{|c|c|c|c|}
\hline $\begin{array}{l}\text { Dependent } \\
\text { Variable }\end{array}$ & $\begin{array}{l}\text { Independent } \\
\text { Variable }\end{array}$ & Explanation & $\begin{array}{l}\text { Expected } \\
\text { Sign }\end{array}$ \\
\hline \multirow{5}{*}{ 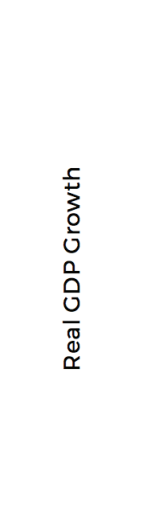 } & Pol & $\begin{array}{l}\text { Political Rights: index measured on a scale } 1 \text { to } \\
7 \text { where } 1 \text { corresponds to the greatest freedom } \\
\text { and } 7 \text { represents the lowest freedom. }\end{array}$ & - \\
\hline & Civil & $\begin{array}{l}\text { Civil Liberties: index measured on a scale } 1 \text { to } 7 \\
\text { where } 1 \text { corresponds to the greatest freedom } \\
\text { and } 7 \text { represents the lowest freedom. }\end{array}$ & - \\
\hline & Trade & $\begin{array}{l}\text { Trade Liberalization: percentage measured by } \\
\text { the product of total export and import divided } \\
\text { by real GDP. }\end{array}$ & + \\
\hline & FDI & $\begin{array}{l}\text { Net Inflows of FDI: percentage measured by the } \\
\text { net inflows of FDI divided by GDP. }\end{array}$ & + \\
\hline & GDPCAP & $\begin{array}{l}\text { GDP per Capita: measured in US\$ by dividing } \\
\text { the total Gross Domestic Product (GDP) with } \\
\text { total population }\end{array}$ & + \\
\hline
\end{tabular}




\section{Independent and Dependent Variables}

The independent variables in this study are: political openness (as defined as political rights and civil liberties) and economic openness (as defined as trade liberalization and net flows of FDI). "Pol" is for political rights and "Civil" is for civil liberties. Data for political rights and civil liberties are taken from the Freedom House data 2013. Each data is annual data, measured on a scale 1 to 7 where 1 corresponds to the greatest freedom and 7 represents the lowest freedom. The same source of data for political rights and civil liberties is also used by other studies such as in Barro (1994) and Fatah et al. (2012).

"Trade" is for trade liberalization measured in the percentage of GDP (total export and import divided by GDP) and it is captured in our regression equations by using trade openness data from UNCTAD. "FDI" is for net flows of FDI measured in the millions of US\$ where the data is also from UNCTAD. Also, in this study I include GDP per capita for the eleven Asian countries from 1984 to 2011.

After all data have been collected, we tabulate them into the descriptive statistics as shown in the Table 2. The mean is the arithmetic average of the scores and it is calculated by dividing the sum of the observation by the number of observations (Agresti and Finlay, 2009). Standard deviation is also used when the data are interval or ratio.

Table 2. Descriptive Statistics

\begin{tabular}{r|rrrrr} 
Variable & Obs & Mean & Std. Dev. & Min & Max \\
\hline Civil & 308 & 3.909091 & 1.352347 & 1 & 7 \\
FDI & 308 & 1227.297 & 17772.42 & -109356.3 & 60144.83 \\
GDP & 308 & 5.561851 & 3.89805 & -13.13 & 15.18 \\
GDPCAP & 308 & 7307.998 & 10907.09 & 246.44 & 37554.18 \\
Pol & 308 & 3.594156 & 1.808656 & 1 & 7 \\
\hline Trade & 308 & 88.58127 & 95.90312 & 13.34 & 445.62 \\
year & 308 & 1997.5 & 8.090892 & 1984 & 2011 \\
code & 308 & 6 & 3.167424 & 1 & 11 \\
reg & 308 & 2 & .7397508 & 1 & 3 \\
r1 & 308 & .2727273 & .4460865 & 0 & 1 \\
\hline r2 & 308 & .4545455 & .4987399 & 0 & 1 \\
r3 & 308 & .2727273 & .4460865 & 0 & 1
\end{tabular}

Also, before running the regression on GDP growth, it is useful to examine the correlations among the variables. According to Table 3 and graph 1, surprisingly the relationship between real GDP growth and political rights and civil liberties is positive even it is not strong. Table 3 also shows that both Trade and FDI are positively correlated with real GDP growth. This is consistent with several studies which supporting the positive impact of economic openness on economic growth. 
Table 3. Correlation Matrix of Variables

\begin{tabular}{|c|c|c|c|c|c|c|}
\hline & GDP & Political & Civil & Trade & FDI & GDPCAP \\
\hline GDP & 1.000 & & & & & \\
\hline Political & 0.3160 & 1.000 & 0.8670 & & & \\
\hline Civil & 0.3518 & 0.8670 & 1.000 & & & \\
\hline Trade & 0.0782 & 0.2035 & 0.1385 & 1.000 & & \\
\hline FDI & 0.4171 & 0.5720 & 0.5537 & 0.1445 & 1.000 & \\
\hline GDPCAP & -0.2107 & -0.3520 & -0.4611 & 0.3719 & -0.5021 & 1.000 \\
\hline
\end{tabular}

Graph 1. Scatter Plot of Variables

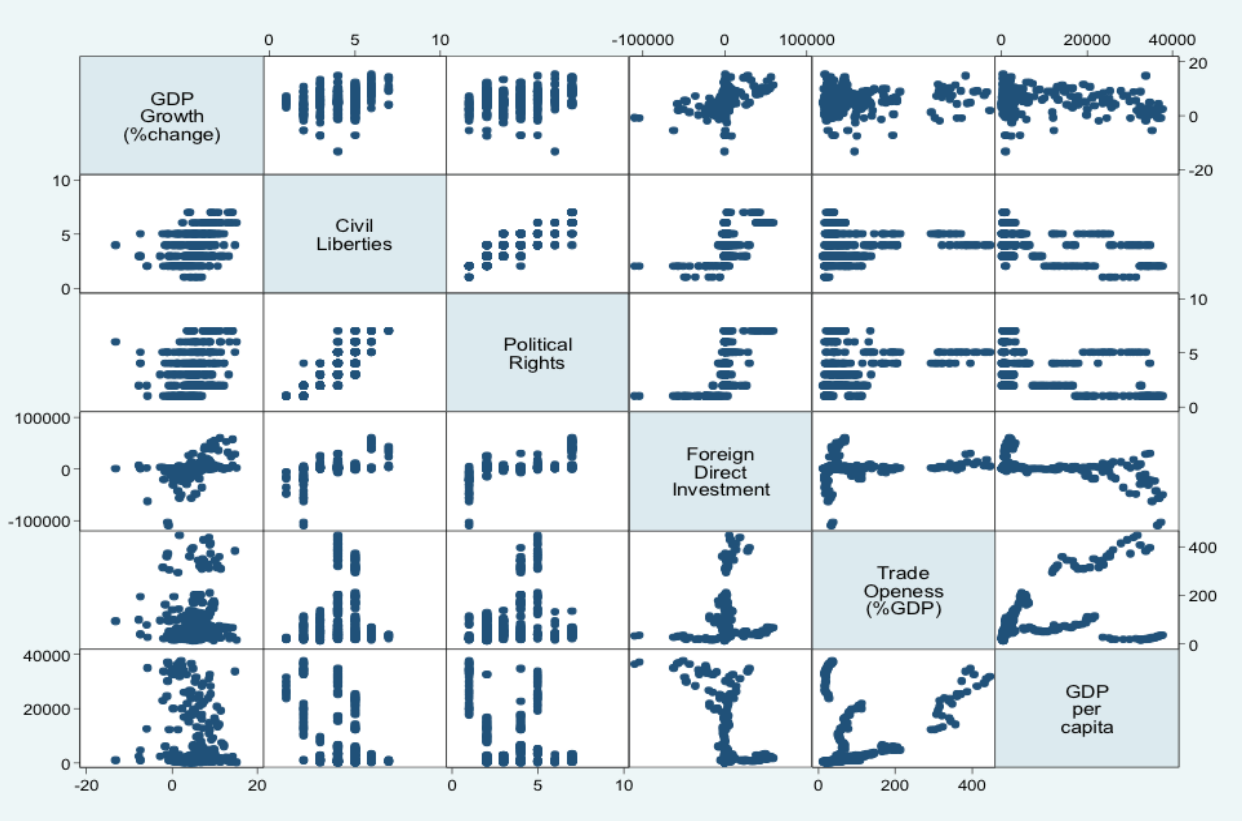

\section{Results and Discussion}

Table 4, 5 and 6 below present the results of the multivariate statistical analysis in this study seperately. Table 4 shows the results from the Pooled OLS. 


\subsection{Pooled OLS}

Table 4. Regression Results for Pooled OLS

\begin{tabular}{|c|c|c|c|c|}
\hline Variable & Model 1 & Model 2 & Model 3 & Model 4 \\
\hline Intercept & $\begin{array}{l}1.6861357 \\
(0.0131)\end{array}$ & $\begin{array}{l}5.3843577 \\
(0.0000)\end{array}$ & $\begin{array}{l}3.3697899 \\
(0.0000)\end{array}$ & $\begin{array}{l}3.0618121 \\
(0.0013)\end{array}$ \\
\hline Political & $\begin{array}{l}0.09364517 \\
(0.6873)\end{array}$ & & $\begin{array}{l}-0.18051665 \\
(0.4367)\end{array}$ & $\begin{array}{l}-0.208432 \\
(0.4728)\end{array}$ \\
\hline Civil & $\begin{array}{l}0.90536131 \\
(0.0038)\end{array}$ & & $\begin{array}{l}0.69078588 \\
(0.0232)\end{array}$ & $\begin{array}{l}0.77722568 \\
(0.0545)\end{array}$ \\
\hline Trade & & $\begin{array}{l}0.00074428 \\
(0.7279)\end{array}$ & $\begin{array}{l}0.00058281 \\
(0.7862)\end{array}$ & $\begin{array}{l}-0.00062634 \\
(0.8052)\end{array}$ \\
\hline FDI & & $\begin{array}{l}0.0000909 \\
(0.0000)\end{array}$ & $\begin{array}{l}0.00007243 \\
(0.0000)\end{array}$ & $\begin{array}{l}0.00007853 \\
(0.0000)\end{array}$ \\
\hline GDPCAP & & & & $\begin{array}{l}0.00002327 \\
(0.3695)\end{array}$ \\
\hline $\mathrm{R}^{2}$ & 0.12 & 0.17 & 0.19 & 0.19 \\
\hline $\mathrm{N}$ & 308 & 308 & 308 & 308 \\
\hline
\end{tabular}

Dependent variable: Real GDP growth

$P$ statistics are in parentheses

According to Table 4, in eleven Asian countries, political rights and civil liberties have a positive relationship with real GDP growth particularly in model 1. However, in model 3 and 4 political rights has a negative relationship though both of them are statistically insignificant. The estimated coefficients for political rights are 0.093 on the first model, -0.180 on the third model and -0.208 on the fourth model. I interpret the coefficient on the first model as a 1 point increase in political rights (less freedom), on average, which would increase the real GDP growth by about US\$ 0.093 percent per year, holding all variables in the equation constant. In the third model, the estimated coefficient is -0.180 . I interpret the coefficient as a 1 point increase in political rights (less freedom), on average, which would decrease the real GDP growth by about 0.180 percent per year, holding all variables in the equation constant. Also, I interpret the coefficient on the fourth model as a 1 point increase in political rights (less freedom), on average, which would decrease the real GDP growth by about 0. 208 percent per year, holding all variables in the equation constant. 
The estimated coefficients for civil liberties (Civil) on the first, third and the fourth model are $0.905,0.691$ and 0.777 respectively. In the first model, it means that every 1 point increase in civil liberties (less freedom), on average, which would increase the real GDP growth by about 0.905 percent per year, holding all variables in the equation constant. In the third model it means that every 1 point increase in civil liberties (less freedom), on average, would increase the real GDP growth by about 0.691 percent per year, holding all variables in the equation constant. Also, I interpret the coefficient on the fourth model as a 1 point increase in political rights (less freedom), on average, which would increase the real GDP growth by about 0. 777 percent per year, holding all variables in the equation constant. It is important to remember that all coefficients are statistically significant at 10 percent error level.

Along with the results in political openness, the regressions of economic openness also show an unexpected result especially on the fourth model where the estimated coefficient for trade liberalization (Trade) is -0.0006 . It means that every 1 percent increase in trade liberalization, on average, will decrease real GDP per-capita by about 0.0006 percent per year, holding all variables in the equation constant. However, on all models the coefficients for tarde liberalization are not statistically significant.

The estimated coefficients for inflows of FDI on all models show expected sign which is positive relationship. In the second model we interpret that every US\$1 million increases in net inflows of FDI, on average, will increase real GDP growth by about 0.00009 per year or every US\$ 1 billion increase increases, will increase the real GDP growth by about 0.09 percent per year. In the third model, the estimated coefficient of FDI is 0.00007 that means US\$ 1 million increases in net inflows of FDI will increase the real GDP growth by about 0.00007 percent per year, holding all variables in the equation constant. In other words, every US\$ 1 billion increases in net inflows of FDI will increase the real GDP growth by 0.07 percent per year.

Even though some signs for estimated coefficients between models for same variables are opposed, it is not hard to explain. The size of the sample we use is small (only 11 countries and 28 years) therefore, the result is not stable.

Then, how to explain the unexpected sign of the coefficients? One answer is that there is an error of specification in this model. However, to know the right answer, continuing researches are needed.

By using this pooled OLS method, it is indicated that form the political openness, only civil liberties is having significant impact on economic growth than political rights, even though the sign is different than I expect. Whereas from the economic openness, net inflows of FDI is more significant than trade liberalization.

\subsection{Fixed Effect vs Random Effect}

In this section, I will show the 2 tables from two different methods and I will evaluate which model is better according to the Hausman Test.

Table 5. Regression Results for Fixed Effect

\begin{tabular}{lllll}
\hline Variable & Model 1 & Model 2 & Model 3 & Model 4 \\
\hline & & & & \\
Intercept & 4.5475751 & 6.8336201 & 5.7531566 & 6.5798932 \\
& $(0.0002)$ & $(0.0000)$ & $(0.0000)$ & $(0.0061)$
\end{tabular}




\begin{tabular}{|c|c|c|c|c|}
\hline Political & $\begin{array}{l}-0.07277295 \\
(0.7533)\end{array}$ & & $\begin{array}{l}-.08616648 \\
(0.7170)\end{array}$ & $\begin{array}{l}-0.07090256 \\
(0.7885)\end{array}$ \\
\hline Civil & $\begin{array}{l}0.32637585 \\
(0.3730)\end{array}$ & & $\begin{array}{l}0.30970651 \\
(0.4213)\end{array}$ & $\begin{array}{l}0.15400186 \\
(0.7534)\end{array}$ \\
\hline Trade & & $\begin{array}{l}-0.01489158 \\
(0.0877)\end{array}$ & $\begin{array}{l}-0.01289194 \\
(0.1567)\end{array}$ & $\begin{array}{l}-0.00116389 \\
(0.9562)\end{array}$ \\
\hline FDI & & $\begin{array}{l}0.00003858 \\
(0.0349)\end{array}$ & $\begin{array}{l}0.0000405 \\
(0.0292)\end{array}$ & $\begin{array}{l}0.00003155 \\
(0.1906)\end{array}$ \\
\hline GDPCAP & & & & $\begin{array}{l}0.000020622 \\
(0.1453)\end{array}$ \\
\hline $\mathrm{R}^{2}$ & 0.002 & 0.021 & 0.023 & 0.044 \\
\hline $\mathrm{N}$ & 308 & 308 & 308 & 308 \\
\hline
\end{tabular}

Dependent variable: Real GDP growth

$P$ statistics are in parentheses

Table 6. Regression Results for Random Effect

\begin{tabular}{|c|c|c|c|c|}
\hline Variable & Model 1 & Model 2 & Model 3 & Model 4 \\
\hline Intercept & $\begin{array}{l}3.1923782 \\
(0.0031)\end{array}$ & $\begin{array}{l}5.5299644 \\
(0.0000)\end{array}$ & $\begin{array}{l}3.5080042 \\
(0.0008)\end{array}$ & $\begin{array}{l}3.4182934 \\
(0.0121)\end{array}$ \\
\hline Political & $\begin{array}{l}.00358018 \\
(0.9874)\end{array}$ & & $\begin{array}{l}-0.13485271 \\
(0.5608)\end{array}$ & $\begin{array}{l}-0.14844292 \\
(0.6004)\end{array}$ \\
\hline Civil & $\begin{array}{l}0.60285237 \\
(0.0720)\end{array}$ & & $\begin{array}{l}0.65338584 \\
(0.0443)\end{array}$ & $\begin{array}{l}0.66926524 \\
(0.2098)\end{array}$ \\
\hline Trade & & $\begin{array}{l}-0.00055738 \\
(0.8723)\end{array}$ & $\begin{array}{l}- \\
0.00093095 \\
(0.8110)\end{array}$ & $\begin{array}{l}0.00051565 \\
(0.8804)\end{array}$ \\
\hline
\end{tabular}


FDI $0.00006621 \quad 0.00005447 \quad 0.00006109$

$(0.0000) \quad(0.0007) \quad(0.0005)$

\begin{tabular}{lllll} 
GDPCAP & & & & - \\
& & & & 0.000008182 \\
& & & $(0.8390)$ \\
$\mathrm{r}^{2}{ }^{\circ}$ & 0.12 & 0.17 & 0.19 & 0.19 \\
$\mathrm{~N}$ & 308 & 308 & 308 & 308 \\
rho & 0.16 & 0.07 & 0.10 & 0.03 \\
\hline
\end{tabular}

Dependent variable: Real GDP growth

$P$ statistics are in parentheses

Table 5 and 6 reports the results across various models using Fixed and Random effect respectively. Columns 1 and 2 show the results of using political openness and economic openness separately. Column 3 shows the results of using both openness altogether whereas in column 4, I add GDP per capita as an independent variable.

As we can see that from table 5 and 6 , political rights has negative signs, means that it has negative relationship with the real GDP growth. These results are similar with the Pooled OLS method. Although they are not significant, civil liberties give us unexpected sign on both tables. Coefficients on FDI are quite consistent on both tables and always have positive signs which mean any increases in FDI will also increase the real GDP growth.

\section{Conclusion and Policy Implication}

The focus of this study is to analyze the impact of political and economic openness on economic performance, particularly in eleven Asian countries. I will conclude the results on table 7 below.

Table 7. Statistical Comparison

\begin{tabular}{lllll}
\hline Variable & Pooled OLS & Fixed Effect & $\begin{array}{l}\text { Random } \\
\text { Effect }\end{array}$ & PCSE* $^{*}$ \\
\hline Intercept & 3.0618121 & $\begin{array}{l}6.5798932 \\
(0.0061)\end{array}$ & $\begin{array}{l}3.4182934 \\
(0.0121)\end{array}$ & $\begin{array}{l}3.061812 \\
(0.001)\end{array}$ \\
& $(0.0013)$ & & & \\
Political & -0.208432 & -0.07090256 & -0.14844292 & -0.208432 \\
& $(0.4728)$ & $(0.7885)$ & $(0.6004)$ & $(0.370)$ \\
& & & & \\
Civil & 0.77722568 & 0.15400186 & 0.66926524 & 0.7772257 \\
& $(0.0545)$ & $(0.7534)$ & $(0.2098)$ & $(0.036)$
\end{tabular}




$\begin{array}{lllll}\text { Trade } & \begin{array}{l}-0.00062634 \\ (0.8052)\end{array} & \begin{array}{l}-0.00116389 \\ (0.9562)\end{array} & \begin{array}{l}0.00051565 \\ (0.8804)\end{array} & \begin{array}{l}-0.0006263 \\ (0.833)\end{array} \\ & & & & \\ \text { FDI } & \begin{array}{l}0.00007853 \\ (0.0000)\end{array} & \begin{array}{l}0.00003155 \\ (0.1906)\end{array} & \begin{array}{l}0.00006109 \\ (0.0005)\end{array} & \begin{array}{l}0.0000785 \\ (0.000)\end{array} \\ & & & & \\ & & & & \\ \text { GDPCAP } & 0.00002327 & 0.000020622 & - & 0.0000233 \\ & (0.3695) & (0.1453) & 0.000008182 & (0.361) \\ & & & 0.8390) & \\ \mathrm{R}^{2} & 0.12 & 0.17 & 0.19 & 0.19 \\ \mathrm{~N} & 308 & 308 & 308 & 308\end{array}$

Dependent variable: Real GDP growth

$P$ statistics are in parentheses

*PCSE is Panel Corrected Standard Error

\subsection{Conclusion}

Many studies and previous literatures suggest that political stability or increase in political right and civil liberty often leads to rapid economic growth. I find some empirical evidence that supports this theory. According to this study, in terms of political openness, political rights can better explain the increase in real GDP growth in Asian countries even though the coefficient is not statistically significant on all methods. This finding is supporting research results done by Fatah et. al (2012). While this variable gives us an expected sign, civil liberties gives us positive sign which is opposed to our hypothesis. I also find a weak direct link between civil liberties and economic growth on all methods. Not only it gives us unexpected signs but also the coefficients are significant only on Pooled OLS and PCSE methods.

In terms of economic openness, only FDI can better explain the impact on the real GDP growth while trade liberalization is ambiguous since it changes sign. All four regression models on all statistical methods indicate that FDI has a positive, strong association with GDP growth. The estimated coefficients have the expected signs and are statistically significant. These results confirm the earlier findings that FDI foster economic growth.

The R2 for our region specification is ranging from 0.12 to 0.19 , indicating that this set of variables explains about 12 to 19 percent of the variation in economic growth. Of course, some countries may differ in terms of magnitude of relationship, considering that the average relationships across countries are not a precise recipe applicable to all countries across time.

\subsection{Policy Implication}

This study examines the impact of economic openness (in the form of trade liberalization and net inflows of FDI) and political openness (political rights and civil liberties) in eleven Asian countries (China, Japan, South Korea, Indonesia, Malaysia, Philippines, Thailand, Singapore, India, Pakistan and Bangladesh) in the period of 1984 - 2011. Using the cross-country growth regression, the results show that FDI and 
political freedom variables are significant determinants of economic growth.

Of course, this framework does not fully explain all the critical factors that accelerates economic growth and does not wholly capture the relationships between macroeconomic variables, policy variables, natural resources and economic outcomes. However, it does highlight several important elements that contribute to rapid economic growth in these economies. Each country has its own policy and different approaches to gear towards robust economic growth. Given real GDP growth is not a good measure of development for the countries as a whole, due to lack of inclusiveness of the measure, no indicator of the degree inequality in income distribution, differences in the exchange rates, population and prices of goods and services, it is very difficult to do a comparative analysis across countries and it is not surprisingly to see the discrepancies between the region and each country growth regressions.

In this study, the main factors that explain rapid economic growth in Asian are FDI and political freedom. With the incentive policy of Reforms Opening Up, China for example has successfully attracted foreign technology and capital which has triggered technological progress and accelerates economic growth.

A negatively significant sign of political freedoms is found to be significantly stimulating economic growth. These results will strengthen the view that societies with greater democratic tend to have higher level of GDP growth. These findings can propose important considerations for policymakers in these countries. The empirical evidence suggests that FDI and political rights are main elements to enhance Asian's economic growth. These countries could consider to formulate policy that will attract and benefit more from FDI inflows and greater openness.

The limitation of our research is obvious that: 1. The size of our sample is small that biases exist and 2. The depth of our knowledge with respect to this field is shallow. Therefore, the amount of information this article contains is limited.

Therefore, for future research, I suggest using a larger sized panel dataset than what this study uses. Instead of emphasizing particular numbers of states in East, South East and South Asian, a sample that includes all countries in Asian is valuable. Also, a new model that contains variables from cultural, geographic and historical dimensions should be considered. 


\section{References}

Aggarwal, R. and T. Agmon. (1990). The International Success of Developing Countries Firms: Role of Government-Directed Comparative Advantage. MIR, (1990).163-180

Agresti, A., B. Finlay. (2009). Statistical Methods for the Social Sciences. Prentice Hall. 2009

Baba, Stephen A.(1997). Democracy and Inefficiency. Economics and Politics 9; 99-114.

Barro, R. J. (1994). Democracy and Growth. National Bureau of Economic Research. Working Paper No. 4909. 1994

(1999). Determinants of Democracy. Journal of Political Economy, 107 (S6) 158-183.

Bhagwati, J. (1993). The Case of Free Trade. Scientific American 269 (5): 18-23.

Balassa, B. (1978). Exports and Economic Growth: Further Evidence. Journal of Development Economics 5:181-189

Benyishay, A., Roger. R. Betancourt (2010). Civil Liberties and Economic Development. Journal of Institutional Economics, 6:3. (2010): 281-304

Berggren, N. (2003). The Benefits of Economic Freedom: A Survey. The Independent Review 8(2)(Fall): 193-211.

Bessette, Joseph M., John J. Pitney. (2012). American Government and Politics: deliberation, democracy and citizenship. (the 2 nd edition). Unpublished.

Daly, H.E (2003). The Perils of Free Trade. Scientific American. Vol. 269 No. 3 November 1993.

Dollar, D., and A. Kraay. (2000). Trade, Growth, and Poverty. Finance and Development, 38, 16-19.

Dominte, L. (2005). Determinants and Effects of Economic Openness. Also available at: http://anale.feaa.uaic.ro/anale/resurse/38_Dominte_L Determinants_and_effects_of_economic_openness.pdf

Driffield, Nigel, James H Love. (2007). Linking $F \bar{D} I$ motivation and host economy productivity effects: conceptual and empirical analysis. Journal of International Business Studies 38, 460-473 (1 May 2007) | doi:10.1057 palgravejibs. 8400268

Fatah, F. Abdul, Nasuddin Othman, Shamsiah Abdullah (2012). Economic Growth, Political Freedom and Human Development: China, Indonesia and Malaysia. International Journal of Business and Social Science Vol. 3 No. 1; January 2012.

Feng, Y. (1997). Democracy, Political Stability and Economic Growth. British Journal of Political Science 27(3)(July): 391-418.

(2003). Democracy, Governance, and Economic Performance: Theory and Evidence. MIT Press.

Feridhanusetyawan, T and Y. Rizal (1998). Liberalisasi Perdagangan Dunia: Bagaimana Manfaatnya bagi ASEAN. Analysis Center for Strategic and International Studies. CSIS. 27 (3) 258-278

Freedom House. (2013). Freedom in the World: The Annual Survey of Political Rights and Civil Liberties, 2012-2013. New York: Freedom House.

Garibay, M. González, Karoline Van den Brande, Myriam Martins Gistelinck, Rafaël Peels and Maarten Vidal (2008). Political Openness : An Assessment of Democracy. Working Paper No. 14 - May 2008.

Gordillo, M.Vega and Jose A. Arce. (2003). Economic Growth and Freedom: A Causality Study. Cato Journal 23:2, Fall: 199-215. Available at : www freetheworld.com/papers/Vega-Gordillo.pdf

Griswold, D. (2007). Trade, Democracy and Peace: the Virtuous Cycle. Paper 
presented at the Peace Through Trade Conference, World Trade Center Association, Oslo, Norway, April 2007.

Haryadi. (2008). The Impact of Agricultural Trade Liberalization on the Developed and Developing Countries. Available at: http://haryadikamal.wordpress com/2010/07/23/dampak-penghapusan-hambatan-perdagangan-sektor pertanian-terhadap-kinerja-ekonomi-negara-maju-dan-berkembang.

Heller, P.S and R.C. Porter. (1978). Exports \& Growth: An Empirical Re-Investigation. Journal of Development Economics , 5, 191-193

Heo, U., Alexander C. Tan. (2001). Democracy and Economic Growth: A Causal Analysis. Comparative Politics. 33(4)(July): 463-473.

Helliwell, John F. 1994. "Empirical Linkages between Democracy and Economic Growth." British Journal of Political Science. 24(2)(April): 225-248.

Karras, G. 2003). Trade Openness and Economic Growth: Can We Estimate the Precise Effect? Applied Econometrics and International Development. AEEADE. Vol. 3-1 (2003)

Matusz, S.J (1999). Adjusting to Trade Policy Reform. Policy Research Working Paper 2142. The World Bank Report.

Michaely, M. (1977). Exports and growth: An empirical investigation. Journal of Development Economics 4, no. 1, March, 49-54.

Mulyono, S (1977). Kecenderungan ekonomi dunia, perdagangan bebas dan pengaruhnya pada ekonomi Indonesia. Fakultas ekonomi Indonesia no. 0040. Jakarta.

Nalley, L., and Andrew Barkley (2005). "Political Freedom, Economic Freedom, and Prosperity: International Trade Policy as a Measure of Economic Freedom." Journal of Private Enterprise, Volume XX1, Fall 2005.

Rodrik, Dani. 2000. Participatory Politics, Social Cooperation, and Economic Stability. American Economic Review Papers and Proceedings 90(2): 140 144.

Przeworski, A., F. Limongi (1993). Political regimes and Economic Growth. The Journal of Economic Perspectives. Vol 7, no.3: 51-69

Tian, Xiaowen. (2007). Accounting for sources of FDI Technology Spillovers: Evidence from China. Journal of International Business Studies, Vol 38, No.1 (2007), pp147-159

Wittman, D. A. (1989), 'Why Democracies Produce Efficient Results', Journal of Political Economy. 97, 6, 1395-424. (1995), The Myth of Democratic Failure: Why Political Institutions Are Efficient (Chicago: Chicago University Press). World Bank. (2013). World Bank development indicators 2012. Retrieved from: http://data.worldbank org/indicator 